\author{
К. В. Осипова \\ Уральский федеральный университет \\ Екатеринбург, Россия \\ zwierze@yandex.ru
}

\title{
Названия блюд из мяса на Русском Севере: этнолингвистический аспект*
}

В докладе рассмотрены диалектные наименования мясных продуктов и блюд из мяса, распространенных на Русском Севере. Исследование основывается на материале лексической картотеки Топонимической экспедиции УрФУ и картотеки «Словаря говоров Русского Севера», а также данных словарей, охватывающих территорию Архангельской, Вологодской и севера Костромской области. В ходе этнолингвистического анализа получают семантико-мотивационную интерпретацию диалектные названия блюд из мяса, характеризуется роль мясной пищи в традиционном рационе, определяются регламентации, связанные с употреблением мяса, а также выявляются его ритуальные функции.

В рационе крестьян Русского Севера мясо и блюда из него были скорее исключением, нежели повседневной пищей. Блюда из мяса регулярно ели зажиточные крестьяне в скоромные дни, а в бедных семьях мясо употребляли в праздники осенне-зимнего периода, когда принято было резать скотину: «Богатые почитай весь год мясо едят, а у нужных и без его обходятся». Мясным блюдом обязательно угощали на помочах, поскольку «за артельным столом крестьяне едят так, как дома позволяют себе только в большие праздники».

Бо́льшую часть заготовленного мяса крестьяне продавали или сдавали государству (мяснало́zи в советский период), оставляя на собственные нужды преимущественно субпродукты. Из субпродуктов в пищу шли печень, кишки, легкое, однако не ели, считая нечистыми, «срамных мест, больших и широких кишок» (Вел.), горло, желчный пузырь (Гряз.). Мясо, в частности говядина, считалось лакомством. Мясо сохраняли впрок, засаливая и высушивая (арх. ветша́ное мясо,

\footnotetext{
* Исследование выполнено при поддержке гранта РНФ «Контактные и генетические связи севернорусской лексики и ономастики» (проект 17-18-01351).

(с) Осипова К. В., 2019
} 
влг. коко́рка, влг. солени́на, а также арх. (Шенк.) арти́ль 'все мясное, кроме птицы и баранины, запасаемое впрок в сушеном виде’). Иногда готовили полуфабрикат из смеси высушенного мяса, хлеба, лука, картофеля, который брали с собой, например на охоту (арх. су́ра, мурциовка).

Основными блюдами из мяса был густой суп (арх., влг. щии), пироги с мясом (влг. мясник), каши с салом и субпродуктами (влг. са́льник), холодец (арх. дрожа́чка, влг. жу́лей, арх., влг. студень, влг. холо́днее), картофель с мясом, томленные в печи, которые ели, макая хлеб (влг. маку́шка), жаркое (арх. жа́рница, влг. пряжёное мясо). После забоя скотины готовили блюда из субпродуктов - рубца (влг. утро́бица, apx. переперу́ха), легкого (арх. легкое наливное), кишечника (костр. кишо́чниц̧а, влг. начинки, чере́вник, влг., костр. са́льник). Нутряное сало ели, обильно сдабривая им овсяную кашу: «В овсяную крупу внутренностей накладём да салом нальём, вот и сальник по праздникам делали». Такое блюдо нередко готовили по завершении сельских работ. В Мезенском районе Архангельской области сохранились названия блюд из оленьей крови (кровяная шаньга, айба́рча́).

Обедающие придерживались регламентаций употребления мяса за столом: даже угощая гостей, крестьяне первую порцию супа ели с хлебом (кро́шки), а затем только с мясом. Мясо выкладывали на деревянное блюдо, где его резали; есть мясо разрешалось лишь после того, как хозяин говорил: «Начинайте таскать» (влг.).

В народном календаре отразились церковные регламентации употребления мяса (ср. арх. Мясное заговенье 'неделя перед Масленицей', Мясное воскресенье 'воскресенье перед Масленицей', костр. Мясная суббота), а также периоды, когда было принято резать скотину (ср. арх. Свинарное заговенье, арх. Свинобой), ритуально употреблять в пищу мясо (арх. Маланьи-Кишечниць '31 декабря') или приносить его в церковь (арх. анастасиевское мясо). В Вологодской области по случаю зарезанного поросенка устраивали празднество свежина́, куда приглашали гостей и угощали блюдом из крови. Хозяину, режущему скотину, желали: сахар-мясо! (влг., костр.), мясо-репа! (влг.), соль-мясо! (костр.), нож-мясо! (костр.), мясная гора! (влг.).

Будучи редким, но в то же время лакомым и сытным блюдом, мясо было непременной частью свадебного застолья, если оно приходилось на скоромные периоды. Так, после венчания на стол обязательно подавали студень и щи из мяса, а также жареную телятину, пирог 
со свининой, баранью лопатку. Специально к свадьбе готовились: костр. крути́льный пирог 'круглый пирог с мясом, который после совершения свадебного обряда кручения посылают священнику', арх. (Шенк.) куку́й 'пирог с мясом', влг. честь, чесь 'четвертое блюдо за свадебным столом, неразрезанный кусок зажаренного мяса’. С употреблением мяса связана свадебная терминология, ср. арх. распеча́тать поросёнка 'обрядовое действие жениха на свадьбе - разрезать поросенка', влг. ездить на барана 'ездить в гости к родне невесты (о молодоженах)', арх. с жопками ходить 'во время свадьбы предлагать гостям косточку с кусочком мяса за троекратный поцелуй в щеку', влг. ошу́рки 'застолье после свадьбы в доме жениха, собранное из остатков свадебного угощения и на деньги, полученные как выкуп невесты'.

Обособленную семантико-мотивационную группу составляют названия шкварок, вытопок от сала: арх. сморчки́, ши́лега, жми́рки, влг. ошу́рки, чи́роги. Эти слова являются маркерами отдельных территорий. Шкварки считались лакомством: их добавляли в кашу или ели самостоятельно. Названия шкварок интересны вторичными значениями, в том числе метеорологическими (диал. шир. распр. сало, арх. шелега́ 'мокрый снег; снег и лед, плывущие по реке') и антропологическими (арх. шилега́ 'о непослушном ребенке', ши́лига 'рассеянный человек'). 